\title{
Elsa de Lavergne, La Naissance du roman policier
}

\author{
Ida Merello
}

\section{(2) OpenEdition}

\section{Journals}

\section{Edizione digitale}

URL: http://journals.openedition.org/studifrancesi/6983

DOI: 10.4000/studifrancesi.6983

ISSN: 2427-5856

\section{Editore}

Rosenberg \& Sellier

\section{Edizione cartacea}

Data di pubblicazione: 1 septembre 2010

Paginazione: 395

ISSN: 0039-2944

\section{Notizia bibliografica digitale}

Ida Merello, «Elsa de Lavergne, La Naissance du roman policier», Studi Francesi [Online], 161 (LIV | II) |

2010, online dal 30 novembre 2015, consultato il 12 janvier 2021. URL: http://

journals.openedition.org/studifrancesi/6983 ; DOI: https://doi.org/10.4000/studifrancesi.6983

Questo documento è stato generato automaticamente il 12 janvier 2021.

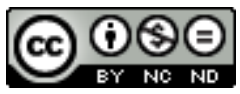

Studi Francesi è distribuita con Licenza Creative Commons Attribuzione - Non commerciale - Non opere derivate 4.0 Internazionale. 


\title{
Elsa de Lavergne, La Naissance du roman policier
}

\author{
Ida Merello
}

\section{NOTIZIA}

ELSA DE LAVERGNE, La Naissance du roman policier, Paris, Classiques Garnier, 2009, pp. 413.

1 L'A. esplora la zona di produzione di romanzi polizieschi compresa tra la morte di Gaboriau (1873) e l'apparizione del primo Arsène Lupin di Maurice Leblanc (1905): territorio ibrido, dove i clichés e le necessità dei feuilletons (moltiplicazione degli intrighi, dei colpi di scena, ecc.) vengono a incontrarsi con le esigenze di una modernizzazione della detective-story. L'A. si sofferma proprio in un primo tempo sui rapporti tra il feuilleton e il poliziesco, rintracciando nel primo quegli elementi che saranno alla base del secondo, sia a livello formale che tematico, per poi procedere alla definizione delle costanti che determinano il nuovo genere, badando altresì agli elementi esterni alla letteratura che potevano condizionarla (ad esempio un contesto attento ai processi criminali sensazionali, una stampa favorevole a dar loro grande risalto, una nuova organizzazione della polizia) e favorivano la creazione di interesse intorno alla figura del moderno poliziotto o al reporter. L'A. affronta il materiale trattato (vale a dire un'ampia selezione di una materia impossibile a gestirsi esaustivamente) isolandone le costanti strutturali e i nodi tematici, cui accosta in annesso anche una serie di fatti di cronaca nera di riferimento, una bio-bibliografia degli autori citati, alcuni pezzi antologici e le mappe del luogo del delitto dei romanzi più celebri, o i rebus e gli schizzi che servono a svelare gli enigmi. 